\title{
Analysis of Influence of Micro Small and Medium Enterprises (MSMEs) Development as a Competitive Advantage to Creative Economic Development
}

Bunga Aditi ${ }^{1}$, Sopi Pentana²

1,2Faculty of Economics and Business, Universitas Harapan, Medan, Indonesia ${ }^{1} E$-mail: bunga.aditi16@gmail.com, ${ }^{2} E$-mail: sopi.pentana@gmail.com

\begin{abstract}
The purpose of this research is to analyze the influence of MSME development as competitive advantage toward creative economic development in Medan city. Data analysis method used in research is path analysis. Simultaneously, the research results of MSME Development and Competitive Advantage have a positive and significant effect on creative economy. Partially, the Influence of MSME Development has positive and significant influence to creative economy. Partially Competitive advantage positively and significantly influences the creative economy. The development of MSME has a positive and significant impact on competitive advantage. Indirectly MSME development positively affects the creative economy through competitive advantage.
\end{abstract}

Key words MSME development, competitive advantage, development of creative economy

JEL Codes: 011, 012, 031

(c) 2018 Published by Dimitrie Cantemir Christian University/Universitara Publishing House.

(This is an open access article under the CC BY-NC license http://creativecommons.org/licenses/by-nc-nd/4.0/)

\section{Introduction}

Nowadays, MSME in various areas is very competitive. This is due to the number of MSMEs operating in Indonesia both operating locally and operating on an international scale. MSMEs sector has a strategic role in contributing to the economic growth of a country, especially the perpetrators of microeconomics which is very much in Indonesia. The main problems faced by MSMEs include the lack of infrastructure and government access related to licensing and bureaucracy, halal certification and high rates of levy. Aditi (2017) states that "product attributes, halal certification, and product innovation have a positive and significant impact on competitive advantage which impact on consumer buy-back (surge) interest, that product attribute, halal certification, and product innovation have positive and significant influence to competitive advantage. With all the problems, the large potential of MSMEs becomes obstructed. Although MSME is said to be able to survive from the global crisis, but in fact the problems faced by MSMEs are very much and heavier. This is because apart from indirectly influenced global crisis before, MSMEs must also face domestic problems that are not resolved such as the problem of labor wages, employment and illegal levies, corruption and so on. The empowerment of MSME in the midst of globalization and high competition make MSME must be able to face global challenge, such as improving product and service innovation, human resource and technology development, and expansion of marketing area. Innovation and creativity of MSME together have a significant effect on consumer satisfaction (Aditi and Hermansyur, 2017). Aditi (2017) also states that "Product Innovation has a positive and significant impact on competitive advantage", that Product Innovation has a positive and significant impact on Competitive Advantage.

This needs to be performed to increase the selling value of MSME itself, especially in order to compete with foreign products that are increasingly flooding the industrial and manufacturing centers in Indonesia, given the MSMEs is the economic sector that is able to absorb the largest workforce in Indonesia (Sudaryanto, 2011). The concept of Creative Economy is gaining major attention in many countries as it can make a real contribution to the economy. In Indonesia, the echoes of the creative economy are starting to sound as governments seek the ways to improve the competitiveness of national products in facing the global markets. The Government through the Ministry of Trade in cooperation with the Ministry of Industry and the Ministry of Cooperatives and Micro Small Medium Enterprises and supported by the Chamber of Commerce and Industry then formed a team of Indonesia Design Power which aims to put Indonesian products into acceptable products in the international market but still has national character. After realizing the enormous contribution of the creative economy to the country, then the government further conducted a more intensive study and launched a blueprint for the development of creative economy. Creative Economy seen from the handicraft sub-sector is a creative activity related to the creation, production and distribution of products made and produced by the craftsmen who originated from the initial design to the process of completion of its products, including handicrafts made from: precious stones, natural fibres as well as artificial, leather, rattan, bamboo, wood, metal (gold, silver, copper, bronze, iron) wood, glass, porcelain, fabrics, marble, clay and lime. Unlike manufacturing industries oriented to the quantity of products, the creative industry is 
more focused on the quality of human resources. The creative industry is more emerging than the small and medium industry group.

\section{Literature review}

\subsection{MSME Development}

Based on Law Number 20 Year 2008 regarding Micro, Small and Medium Enterprises (MSMEs) there are several criteria that are used:

Table 1. MSME Criteria

\begin{tabular}{|c|c|c|c|}
\hline \multirow{2}{*}{ No } & \multirow{2}{*}{ Enterprises } & \multicolumn{2}{|c|}{ Criteria } \\
\hline & & Asset & Turnover \\
\hline 1. & Micro enterprises & Max 50 million & Max. 300 Million \\
\hline 2. & Micro enterprises & $>50$ Million - 500 Million & $>300$ Million - 2,5 Billion \\
\hline 3. & Medium enterprises & $>500$ Million - 10 Million & $>2,5$ Billion - 50 Billion \\
\hline
\end{tabular}

Source: Ministry of Cooperatives and Small and Medium Enterprises, (2012).

Based on the MSMEs Law, from the perspective of its development, Rahmana (2008) classified MSMEs in several criteria, namely: (1) Livelihood Activities, is a Small and Medium Business that is used as a job opportunity to earn a living, which is more commonly known as the informal sector. The examples are street vendors. (2) Micro Enterprise is a Small and Medium Enterprises that has the nature of craftsmen but does not have the nature of entrepreneurship. (3) Small Dynamic Enterprise, is a Business that already has an entrepreneurial spirit and is able to accept subcontract and export work. (4) Fast Moving Enterprise, is a Business that already has an entrepreneurial spirit and will make a transformation into a Big Enterprise (UB).

\subsection{Competitive Advantages}

Competitive advantage is a state in which a company can create a good defense position over its competitors (Li et.al, 2010). Another notion is conveyed by Hill and Jones (2010) states that competitive advantage is based on a special competence, that is, the specific strengths of a company that can make a company able to make its product different from the products that the competitors offer and have lower prices than competitors. Competitive advantage according to Tjiptono (2010) is something that allows companies to earn higher than average profit. According to Kim and Mauborgne in (Kadarningsih, 2013) said that in the competition market there are two oceans namely Red Ocean (Red Ocean) and Blue Ocean (Blue Ocean).The Theory of Creative Economy according to Richard Florida, a Doctor in Economics, Dr. Richard Florida from America, the author of "The Rise of Creative Class" and "Cities and the Creative Class" introduces the creative economy and creative class in the community (Creative Class). Places and cities that are able to create the fastest innovative new products will win the competition in this economic era. "(Nenny, 2008). Places and cities that are able to create the fastest innovative new products will win the competition in this economic era." (Nenny, 2008). Creative economy is the economy derived from the utilization of creativity, skills and individual talents to create welfare and employment by generating and exploiting the creative power and the creativity of these individuals (Indonesia Kreatif, 2014). The creative economy is seen as increasingly important in supporting prosperity in the economy because today will depend on the production of knowledge through creativity and innovation (Bianchini, 2008).

\subsection{Conceptual Framework}

Conceptual framework in this research can be seen in Figure 1:

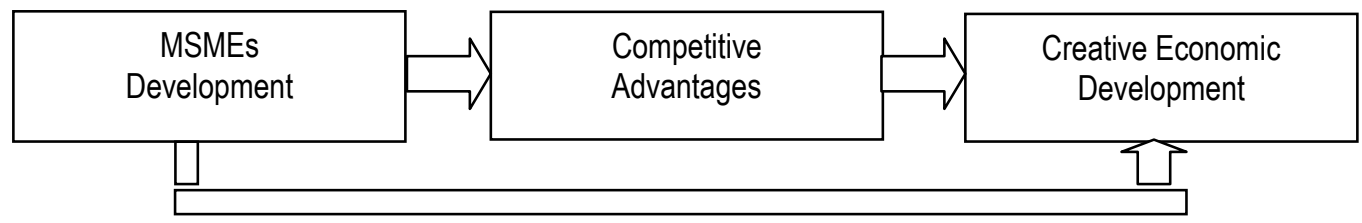

Figure 1. Conceptual Framework

\section{Methodology of research}

In identification and operational there are creative economic dependent variable $(Y)$, independent variable of MSME development $(X)$ and intervening variable of competitive advantage $(Z)$. The population in this research is all the community 
who are involved in MSME activities registered in the Department of MSMEs Medan. Research population is a collection of objects determined through a certain criteria that will be categorized into the object can include people, documents or records that are viewed as research objects (Badaruddin et al., 2017; Achmad et al 2017). The sampling technique used in this research is the method of census or saturated samples that is all populations used or used as a sample (Sugiyono, 2010). Hair et al., 2007; Rasdianto et al., 2014; Maksum et al., 2014; Pohan et al., 2018; Lubis et al., 2018; Marhayanie et al., 2018; Muda, 2018) still recommend to use a sample of at least 100 respondents to provide better results. According Muda and Rafiki (2014) and Muda et al. (2014) if the value of the validity of each question is greater than the value of correlation coefficient (r) 0.30 then the questionnaire is considered valid. Validity test is done by one-time method (one shot method) where the measurement with this method is done only once. Methods of data analysis used with path analysis. Path analysis is a developmental technique of multiple linear regressions:

Sub Model l: $\quad Z=a+b_{1} X_{1}+e_{1}$

Sub Model II: $\quad Y=a+b_{1} X_{1}+b_{2} Z+e_{2}$

1. Determination Coefficient Analysis $\left(R^{2}\right)$

The coefficient of determination $\left(R^{2}\right)$ essentially measures the extent of the model's ability to explain the variables of dependent variables Suriadi et al., 2015; Syahyunan et al, 2017; Sirojuzilam et al, 2017; Sihombing et al., 2017; Tarmizi et al., 2016, 2017; Yahya et al., 2017; Erlina et al., 2018; Sari et al., 2018; Sadalia et al., 2018; Eriadi et al., 2018; Muda et al., 2018).

\section{Simultaneous Test (F-Test)}

If $\mathrm{F}_{\text {count }}<\mathrm{F}_{\text {table, }}$, then $\mathrm{H}_{0}$ is accepted and $\mathrm{H}_{a}$ is rejected, and If $\mathrm{F}_{\text {coun }}>\mathrm{F}_{\text {table }}$, then $\mathrm{H}_{0}$ is rejected and $\mathrm{H}_{\mathrm{a}}$ accepted.

3. Partial / Individual Test (t-Test)

Partial test or t-test is to test whether an independent variable has an individual effect on the dependent variable.

\section{Results and discussions}

\subsection{Normality Test}

The result of normality test can be seen in Figure 2:

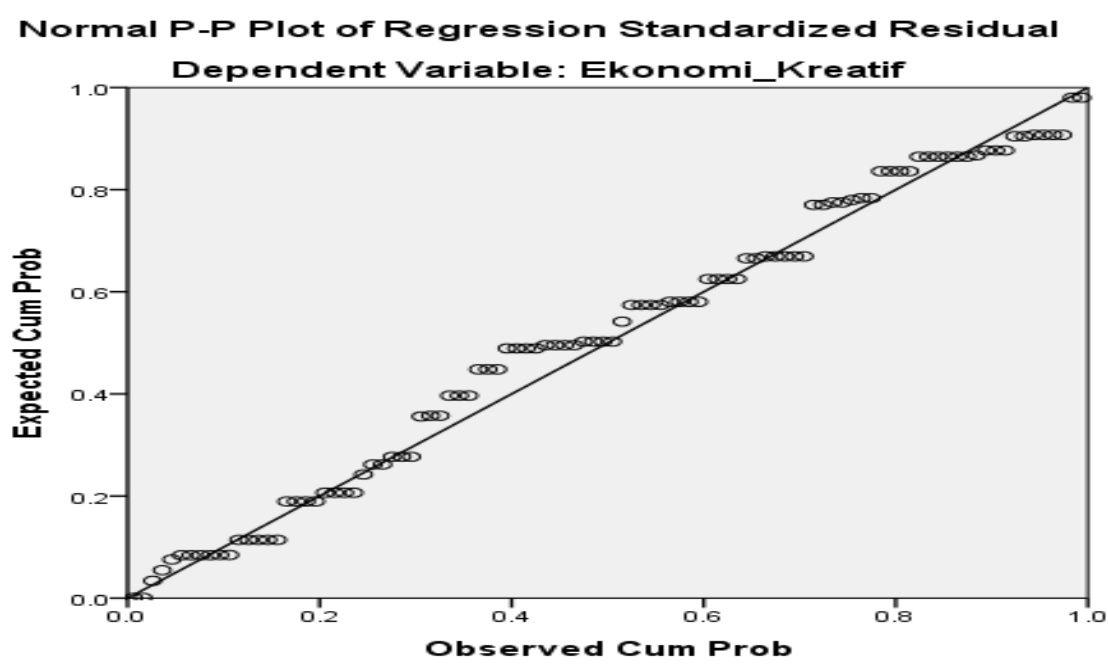

Source: Results of Research, 2018 (Processed Data).

\section{Figure 2. SPSS Results Scatter Chart}

According to Khaldun et al., (2014); Hasan et al., (2017); Yahya et al., (2017); Lubis et al., (2017); Muda et al., 2018; Lubis et al., (2018); Muda et al., (2018) the normality test is to compare the data we have with normal distributed data having the mean and standard deviation equal to our data. Good data and feasible to be used in research is data that has a normal distribution. Figure 2 shows the data spread around the diagonal line. This explains that the data regressed in this research is normally distributed. 


\subsection{Multicolinearity Test}

The results of multicollinearity test can be seen in Table 2 :

Table 2. Results of Multicollinearity Test

\begin{tabular}{lllll}
\hline & \multirow{2}{*}{ Model } & \multirow{2}{*}{ Sig. } & \multicolumn{2}{c}{ Collinearity Statistics } \\
\cline { 3 - 5 } 1 & & .000 & & Tolerance \\
\hline \multirow{2}{*}{1} & (Constant) & .000 & .707 & 1.415 \\
\cline { 2 - 5 } & MSME_Development & .000 & .707 & 1.415 \\
\cline { 2 - 5 } & Competitive_Advantages & &
\end{tabular}

a. Dependent Variable: Creative_Economy

Source: Results of Research, 2018 (Processed Data).

The Table to see that cannot determine causal relationships variable and cannot be used as a to see the causal relationship the causal relationship between relationships (Mahdaleta et al., 2016; Lutfi et al., 2016; Lubis et al., 2016; Marhayanie et al., 2017; Azlina et al., 2017; Erlina et al., 2017; Ferine et al., 2017; Handoko et al 2017; Muda et al., 2018; Sihombing et al., 2018).Table 2 shows the VIF and tolerance values of all variables in this research did not experience multicollinearity.

\subsection{Heteroscedasticity Test}

The results of heteroscedasticity test can be seen in Figure 3:

Scatterplot

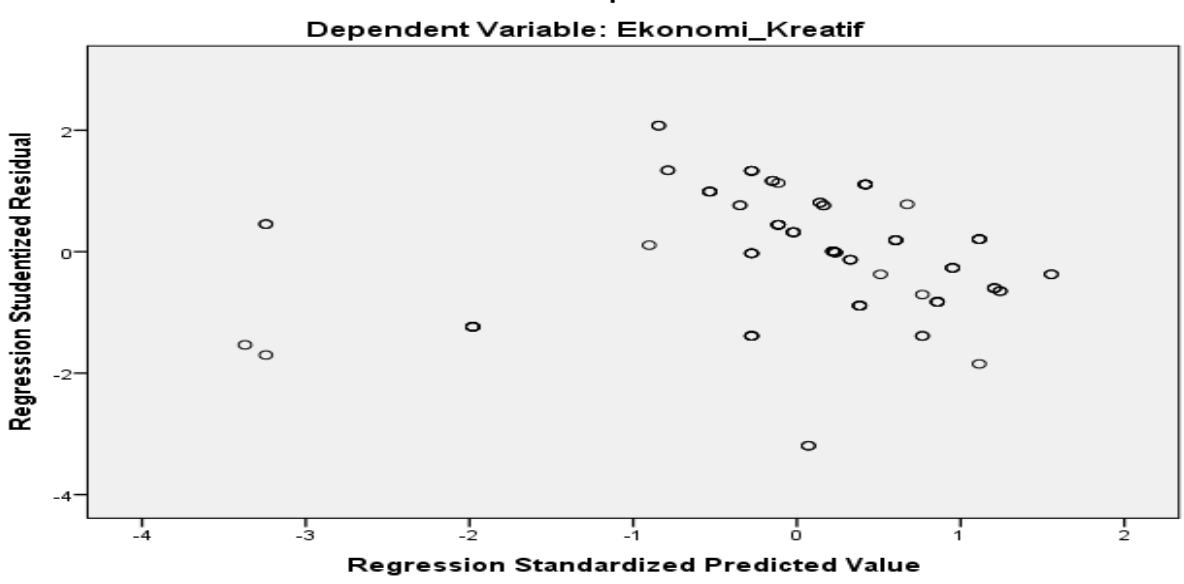

Source: Results of Research, 2018 (Processed Data).

\section{Figure 3. Heteroscedasticity Test}

Figure 3 shows the spreading point does not form certain patterns and spreads well above the number 0 on the axis of Regression Studentized Residual (Y) or absolute residual value (absut) as the dependent variable (Marhayanie et al., 2017; Lubis et al., 2017; Muda, 2017; Syahtunan et al., 2017; Sihombing et al., 2018; Sirojuzilam et al., 2018). If the value of significance $>0.05$, then there is no heterokedastisity.

\subsection{Influence of MSME Development and Competitive Advantage to Creative Economy}

Based on the result of regression equation, the result obtained is in Table 3:

Table 3. Regression Test Results of MSME Development and Competitive Advantage

\begin{tabular}{llccc}
\hline \multirow{2}{*}{ Model } & \multicolumn{2}{c}{ Unstandardized Coefficients } & Standardized Coefficients \\
\cline { 2 - 4 } 1 & B & Std. Error & Beta \\
\hline \multirow{2}{*}{1 (Constant) } & 2.707 & .709 & \\
\cline { 2 - 4 } MSME_Development & .421 & .051 & .606 \\
\hline Competitive_Advantages & .244 & .064 & .281 \\
\hline
\end{tabular}

Source: Results of Research, 2018 (Processed Data). 
Based on Table 3 then the multiple regression equation is: $Y=2,707+0,421 X_{1}+0,244 X_{2}$

1. The regression coefficient $X 1$ for the variable of MSME Development positive value 0,421 means the effect of SME development in line with the improvement of creative economy.

2. The regression coefficient $X 2$ for competitive advantage is positive value 0,244 it means influence of competitive advantage in the same direction with improvement of creative economy.

\subsection{Coefficient of Determination $\left(R^{2}\right)$}

Adjusted $R$ Square Value can be seen in Table 4:

Table 4. Coefficient of Determination Value (R square)

\begin{tabular}{ccccc}
\hline Model & R & R Square & Adjusted R Square & Std. Error of the Estimate \\
\hline 1 & $.794^{a}$ & .630 & .623 & 1.47991 \\
\hline
\end{tabular}

a. Predictors: (Constant), Competitive_Advantages, MSME_Development

b. Dependent Variable: Creative_Economy

Source: Results of Research, 2018 (Processed Data).

The coefficient of determination is between zero and one (Muda and Hutapea, 2018; Muda and Naibaho, 2018; Tripriyono et al., 2018; Muda et al., 2018). The small value of R2 means the ability of the independent variables to explain the variation In Table 4, the coefficient value of Adjusted $\mathrm{R}$ Square is 0,623 , which means that the development of MSME and competitive advantage can explain the variation of creative economy of $62,3 \%$ and the rest is $37,7 \%$ influenced by other variable outside the variables studied.

\subsection{Simultaneous Test}

The result of $F$ test in this research can be seen in Table 5 :

Table 5. Results of Hypothesis Test Simultaneously

\begin{tabular}{lccccc}
\hline \multicolumn{1}{c}{ Model } & Sum of Squares & df & Mean Square & F & Sig. \\
\hline 1 Regression & 362.067 & 2 & 181.033 & 82.659 & $.000^{\mathrm{b}}$ \\
\hline Residual & 212.443 & 97 & 2.190 & & \\
\cline { 2 - 6 } Total & 574.510 & 99 & & & \\
\hline
\end{tabular}

a. Dependent Variable: Creative_Economy

b. Predictors: (Constant), Competitive_Advantages, MSME_Development

Source: Results of Research, 2018 (Processed Data).

In Table 5 , the result of $F_{\text {count }}$ is 82,659 while $F_{\text {table }}$ at $\alpha=0.05$ is obtained $F_{\text {table }} 4.00$ then this result is known that $F_{\text {count }}>$ $F_{\text {table, }}$ and significance 0.000 or less than $\alpha=0.05$.

\subsection{Partial Test}

The results of partial hypothesis test to determine the level of significance with alpha $<0.05$ from each MSME Development and Competitive Advantage to the creative Economy can be seen in Table 6:

Table 6. Results of Hypothesis Test Partially / $\mathrm{t}$ Test

\begin{tabular}{|c|c|c|c|c|c|c|}
\hline & \multirow{2}{*}{ Model } & \multicolumn{2}{|c|}{ Unstandardized Coefficients } & \multirow{2}{*}{$\frac{\text { Standardized Coefficients }}{\text { Beta }}$} & \multirow[b]{2}{*}{$\mathrm{t}$} & \multirow[b]{2}{*}{ Sig. } \\
\hline & & B & Std. Error & & & \\
\hline \multirow{3}{*}{1} & (Constant) & 2.707 & .709 & & 3.819 & \\
\hline & MSME_Development & .421 & .051 & .606 & 8.246 & .000 \\
\hline & $\overline{\text { Competitive_Advantage }}$ & .244 & .064 & 281 & 3.826 & .000 \\
\hline
\end{tabular}

Source: Results of Research, 2018 (Processed Data).

The $t_{\text {count }}$ value for MSME Development $(8,246)$ is greater than the value of $t_{\text {table }}(1.66)$ or the sig $t$ value for MSME Development $(0.000)$ smaller than alpha $(0.05)$ and the $t_{\text {count }}$ value for competitive advantage $(3,826)$ is greater than the $t_{\text {table }}$ value $(1.66)$ or the sig $t$ value for competitive advantage $(0,000)$ smaller than alpha $(0.05)$. 


\subsection{Effect of MSME Development on Competitive Advantage}

Based on the result obtained in Table 7:

Table 7. Regression Test Results of Competitive advantage

\begin{tabular}{llccc}
\hline \multirow{2}{*}{ Model } & \multicolumn{2}{c}{ Unstandardized Coefficients } & Standardized Coefficients \\
\cline { 2 - 4 } & B & Std. Error & Beta \\
\hline \multirow{2}{*}{1 (Constant) } & 4.315 & 1.034 & \\
\cline { 2 - 5 } MSME_Development & .433 & .068 & .542 \\
\hline
\end{tabular}

Source: Results of Research, 2018 (Processed Data).

Based on Table 7, the regression equation is: $Y=4,315+0,433 Z$

The $Z$ regression coefficient for the competitive advantages variable has the positive value of 0,433 . It means that MSME development is in line with the improvement of creative economy.

\subsection{Coefficient of Determination $\left(R^{2}\right)$}

$R$ square value can be seen in Table 8:

Table 8. Coefficient of Determination Value (R square)

\begin{tabular}{ccccc}
\hline Model & $\mathbf{R}$ & $\mathbf{R}$ Square & Adjusted R Square & Std. Error of the Estimate \\
\hline 1 & $.542^{\mathrm{a}}$ & .293 & .286 & 2.34277 \\
\hline
\end{tabular}

Source: Results of Research, 2018 (Processed Data).

In Table 8, the coefficient of determination value ( $R$ square) is 0,741 which means that the development of MSME can explain the variation of the competitive advantage equal to $74,1 \%$ and the rest equal to $25,9 \%$ influenced by other variable outside the variables studied, that is marketing strategy.

4.10. Partial test

Table 9. Results of Hypothesis Test Partially / $\mathrm{t}$ Test

\begin{tabular}{|c|c|c|c|c|c|}
\hline \multirow{2}{*}{ Model } & \multicolumn{2}{|c|}{ Unstandardized Coefficients } & \multirow{2}{*}{$\begin{array}{c}\text { Standardized Coefficients } \\
\text { Beta }\end{array}$} & \multirow{2}{*}{$t$} & \multirow{2}{*}{ Sig } \\
\hline & B & Std. Error & & & \\
\hline (Constant) & 4.315 & 1.034 & & 4.173 & .000 \\
\hline MSME_Development & .433 & .068 & .542 & 6.379 & .000 \\
\hline
\end{tabular}

Source: Results of Research, 2018 (Processed Data).

Based on Table 9, the partial test results are obtained as follows: The $t_{\text {count }}$ value for MSME Development (16.330) is greater than the trable value (1.66), or the sig t value for MSME Development $(0.000)$ smaller than alpha $(0.05)$.

4.11. Influence of MSME Development on creative economy with competitive advantage as intervening variable SPSS output results obtain the regression equation as follows:

$Y=2,707+0,421 X_{1}+0,244 X_{2}$

$Y=4,315+0,433 Z$

Total influence of Development and Competitive Advantage to the creative Economy with creative economy as intervening variable:

Table 10. Results of Hypothesis Test Partially / $\mathrm{t}$ Test

\begin{tabular}{clc}
\hline No & \multicolumn{1}{c}{ Relationship between Variable } & Direct Effect \\
\hline 1 & Effect of MSME Development on Creative Economy & 0.421 \\
\hline 2 & The Influence of Competitive Advantage to the Creative Economy & 0.244 \\
\hline 3 & Effect of MSME Development on Competitive Advantage & 0.433 \\
\hline
\end{tabular}

Source: Research Results, 2018 (processed data). 
The result of indirect intervening variables research: Effect of MSME Development on Creative Economy through Competitive Advantage as intervening variable $=0,421 \times 0,244 \times 0,433=0,044$. The effect of MSME development on creative economy through competitive advantage as intervening variable is $Y=0,421+0,044=0,465$.

Table 11. Summary of Indirect Effect Research Results

\begin{tabular}{ccc}
\hline No & Relationship between Variable & Indirect Effect \\
\hline 1 & Effect of MSME Development on Competitive Advantage and its impact on Creative Economy & 0.465 \\
\hline
\end{tabular}

Source: Research Results, 2018 (processed data).

The research results are as follows: MSMEs Development and competitive advantage directly affect the creative economy and creative economy directly affects the competitive advantage and MSMEs development indirectly affects the creative economy through competitive advantage as intervening variable.

\section{Conclusions and suggestions}

\subsection{Conclusions}

Simultaneously MSME Development and Competitive Advantage have positive and significant influence to creative economy. The MSME development has a positive and significant impact on creative economy. Competitive advantage positively and significantly influence to creative economy. The MSME development has a positive and significant impact on competitive advantage and indirectly MSME development positively influence the creative economy through competitive advantage.

\subsection{Suggestions}

MSMEs should improve competitiveness by improving product quality, business licensing, halal certification. MSMEs should develop the efforts to increase creativity and innovation, pay more attention to the distribution of products and MSMEs should be more concerned about the distribution of products.

\section{References}

Achmad, N; \& Muda, I. (2017). Economic Activities of Karo Older Adults in Lingga Village, Tanah Karo Regency, North Sumatera, Indonesia. International Journal of Economic Research. 14(16). 365-379.

Aditi, B. (2017). The Effect Of Atributes Product's Analysis, Halal Certification, And Product Innovation To The Interest Of Consumer Buying-Back Through The Competitive Advantage Of Micro Small And Medium Business (MSMB) In Medan. In Journal of Physics: Conference Series. Vol 930, No. 1, p. 012020). IOP Publishing.

Aditi, B., \& Hermansyur, H. M. (2017). The influence of product quality, brand image, price, and promotion, to the purchase decision of honda car brand in Medan City. Jkbm (Journal of Business Concepts and Management), 3(2), 154-165.

Agustina. T. A. S., Lubis \& Muda., I., (2018). Various Aspects of The Implementation of SIMDA Which Influence The Quality of Financial Statement with The Role of PPK-SKPD as Moderating Variable (A Case Study at The SKPD of Deli Serdang Regency). Advances in Economics, Business and Management Research (AEBMR). 46. 176-183.

Azlina, N. A.Hasan, Desmiyawati \& Muda, I. (2017). The Effectiveness of Village Fund Management (Case Study at Villages in Coastal Areas in Riau). International Journal of Economic Research. 14(12). 325-336.

Badaruddin; Revida, E; Ermansyah \& Muda, I. (2017). Village Governance With Implementation of Law Number 6 of 2014 On The Village and Village Administration. International Journal of Economic Research. 14(16). 350-363.

Dalimunthe, D.M.J., and Muda, I. (2017). The Empirical Effect of Education and Training to the Performance of Employees. International Journal of Applied Business and Economic Research. 15(24). 5423-5437.

Dalimunthe, D.M.J., Fadli, and Muda, I. (2016). The application of performance measurement system model using Malcolm Baldrige Model (MBM) to support Civil State Apparatus Law (ASN) number 5 of 2014 in Indonesia. International Journal of Applied Business and Economic Research. 14(11). 7397-7407.

Eriadi, Muda, I, and S.Abdullah, (2018). Determinant Analysis of the Quality of Local Government Financial Statements in North Sumatra with the Effectiveness of Management of Regional Property as a Mediator, International Journal of Civil Engineering and Technology, 9(5). 1334-1346.

Erlina and Muda, I, (2018). Determinants Of The Implementation Of Risk-Based Internal Auditing In Regencies/Cities In North Sumatera Province, International Journal of Civil Engineering and Technology, 9(5), 1360 - 1372.

Erlina and Muda, I, (2018). The Effect of Self Efficacy and Professional Development on the Work Quality of Internal Auditor, International Journal of Civil Engineering and Technology, 9(5), 2018, 1292-1304.

Erlina, A.Saputra \& Muda, I. (2017). Antecedents of Budget Quality Empirical Evidence from Provincial Government In Indonesia. International Journal of Economic Research. 14(12). 301-312. 


\section{Academic Journal of Economic Studies}

Vol. 4 (3), pp. 122-132, C 2018 AJES

Erlina. A.Saputra \& Muda, I. (2017). The Analysis of the Influencing Factors of Budget Absorption. International Journal of Economic Research. 14(12). 287-300.

Erwin, K., Abubakar, E., Muda, I. (2018). The relationship of lending, funding, capital, human resource, asset liability management to non-financial sustainability of rural banks (BPRs) in Indonesia. Journal of Applied Economic Sciences, Volume XIII, Spring 2(56). 520 542.

Ferdinand, A. (2006). Management Research Methods. Balai Pustaka UNDIP.

Ferine, K.F; Ermiaty, C. \& Muda, I. (2017). The Impact Of Entrepreneurship And Competence On Small Medium Enterprises Tangan Di Atas (TDA) Medan Entrepreneurs' Work Performance. International Journal of Economic Research. 14(16). 380-393.

Greasley, A. (2006). Operations Management In Business. United Kingdom: Stanley Thomes Ltd.

Gusnardi, Riadi, R.M., and Muda, I. (2016). Competency mapping and analysis of students competency based on economics subject national examination and its alternative solutions in state high schools at Pekanbaru. International Journal of Economic Research. 3(5). 2133-2148.

Hair, J.F, Bush, P.R.Ortinau. J.D. (2006). Marketing Research: Within a Changing Information Environment. 3rd edition, McGraw-Hill / Irwin. New York.

Handoko, ,Bagus. Sunaryo \& Muda, I. (2017). Difference Analysis of Consumer Perception of Motorcycle Product Quality. International Journal of Economic Research. 14(12). 363-379.

Hasan, A, Gusnardi \& Muda, I. (2017). Analysis of Taxpayers and Understanding Awareness Increase in Compliance with Taxpayers Individual Taxpayers. International Journal of Economic Research. 14(12). 75-90.

Hill, C.W.L., Jones, G.R. (2010). Strategic Management: An Integrated Approach: Theory. Mason: Cengage Learning.

Hutagalung, B.; Dalimunthe, D.M.J, R., Pambudi, A.Q. Hutagalung \& Muda, I. (2017). The Effect of Enterpreneurship Education and Family Environment Towards Students' Entrepreneurial Motivation. International Journal of Economic Research. 14(20). 331-348.

Kadarningsih, Ana, (2013). Competitive Advantages; Factors Affecting And Their Impact on Selling-In Performance (Study on Outlet Assistance PT Indosat Semarang). Journal of Media Economics \& Information Technology. 21(1). 1-8.

Khaldun, K. I. \& Muda, I. (2014). The Influence of Profitability And Liquidity Ratios on The Growth of Profit of Manufacturing Companiesa Study of Food And Beverages Sector Companies Listed on Indonesia Stock Exchange (Period 2010-2012). International Journal of Economics, Commerce and Management. 2(12). 1-17.

Kotler, P. and Keller, K.L. (2009). Marketing Management. Issue 13 Volume 1 Jakarta: Erlangga Publishers.

Kotler, P. (2009). Marketing Management. Jakarta: Erlangga Publisher.

Li, S., Nathan, B.R., Nathan, T.S.R., Rao, S.B. (2006). The Impact of Supply Chain Management Practices On Competitive. The International Journal of Management Science. 34(1), 107-124.

Lubis, A., Rustam and Muda, I. (2016). Factors Affecting The Cost of Agency of Village Owned Enterprise (BUMDES) in Indonesia. International Journal of Economic Research. 14(16). 334-348.

Lubis, A., Rustam and Muda, I. (2018). Analysis of Ownership and Stock Composition of Vocational Business Enterprises (BUMDES) and Its Impact on "Omset" of Business Owned Enterprises. Advances in Economics, Business and Management Research (AEBMR), 1st Economics and Business International Conference 2017 (EBIC 2017). 46. 274-277.

Lubis, A.,Torong, Z.B., and Muda, I. (2016). The urgency of implementing balanced scorecard system on local government in North Sumatra - Indonesia. International Journal of Applied Business and Economic Research. 14(11). 7575-7590.

Lubis, A.F., Lubis, T.A., and Muda, I. (2016). The role of Enterprise Resource Plan (ERP) configuration to the timeliness of the financial statement presentation. International Journal of Applied Business and Economic Research. 14(11). 7591-7608.

Lubis, Winni Nadya, (2015), Analysis of Leadership Influence, Work Ability and Motivation on Employee Performance UPT V On Revenue Office Area Medan, USU, Medan.

Lutfi, M.,Nazwar, C., and Muda, I (2016). Effects of investment opportunity set, company size and real activity manipulation of issuers in Indonesia Stock Exchange on stock price in Indonesia. International Journal of Economic Research. 13(5). $2149-2161$.

Mahdaleta, Ela; Muda, I and Gusnardi Muhammad. (2016). Effects of Capital Structure and Profitability on Corporate Value with Company Size as the Moderating Variable of Manufacturing Companies Listed on Indonesia Stock Exchange. Academic Journal of Economic Studies. 2(3). 30-43.

Maksum, A., Hamid, R., \& Muda, I. (2014). The Impact of Treasurer's Experience And Knowledge on The Effectiveness of The Administration and Preparation of The Accountability Reporting System in North Sumatera. Asian Journal of Finance \& Accounting, 6(2), 301-318. http://dx.doi.org/10.5296/ajfa.v6i2.6341.

Marhayanie, M. Ismail and Muda, I, (2017). Impact of The Online Car Rental Service Order System on Sales Turnover with Financial Literacy Customer as Intervening Variables. International Journal of Economic Perspectives. 14(16). 317-332.

Marhayanie, M.Ismail and Muda, I, (2018). Impact of Smartphone Features on "Omset" Services Online Car Rental. Advances in Economics, Business and Management Research (AEBMR). 46. 278-281.

Muda, I and A. A. F. Hutapea. (2018). Influence of capital expenditure and income original region to the income per capita in Indonesia. IOP Conference Series: Earth and Environmental Science. 2018. 126 doi:10.1088/1755-1315/126/1/012065.

Muda, I and A.Dharsuky, (2016). Impact of Capital Investments and Cash Dividend Policy on Regional Development Bank (BPD) PT. Bank Sumut to the District Own Source Revenue and Economic Growth. International Journal of Applied Business and Economic Research, 14(11). 7863-7880. 


\section{Academic Journal of Economic Studies}

Vol. 4 (3), pp. 122-132, C 2018 AJES

Muda, I and Dharsuky, A. (2015). Impact of Region Financial Information System (SIKD) Quality, Role Ambiguity and Training on Precision of Financial Statement of Local Government Presentation in North Sumatra. International Journal of Applied Business and Economic Research, 13(6). 4283-4304.

Muda, I, and Erlina, (2018). Performance Appraisal of Government Internal Supervisory Apparatus (APIP) in Implementation of Compliance Audit at Inspectorate of Medan City, Indonesia, International Journal of Civil Engineering and Technology, 9(5), 2018, 1347-1359.

Muda, I, D.Y.Wardani, Erlina, A.Maksum, A. F.Lubis \& R. Bukit. (2017). The Influence of Human Resources Competency \& The Use of Information Technology on The Quality of Local Government Financial Report with Regional Accounting System as an Intervening. Journal of Theoretical \& Applied Information Technology. 95(19), 1432-1451.

Muda, I, Dharsuky. A., Siregar, H.S., \& Sadalia, I. (2017). combined loading and Cross-dimensional loadings timeliness of presentation of financial statements of local government. IOP Conference Series: Materials Science and Engineering. 180. DOI: 10.1088/1757899X/180/1/012099.

Muda, I, Erlina, I.Yahya and A.A.Nasution, (2018). Performance Audit and Balanced Scorecard Perspective, International Journal of Civil Engineering and Technology, 9(5). 1321-1333.

Muda, I, F Roosmawati, H S Siregar, Ramli, H Manurung \& T Banuas. (2018). Performance Measurement Analysis of Palm Cooperative Cooperation with Using Balanced Scorecard. IOP Conference Series: Materials Science and Engineering 2017. 288. 012081 DOI: 012081 doi:10.1088/1757-899X/288/1/012081.

Muda, I, M. Ismail \& Marhayanie. (2017). Impact Allocation Capital Expenditure on the Improvement of the Local Government Assets in North Sumatra and Effect on Local Revenue Sustainability. International Journal of Economic Perspectives. 11(2). 151-164.

Muda, I, M.Sihombing, E.Jumilawati and A. Dharsuky. (2016). Critical Success Factors Downstream Palm Oil Based Small And Medium Enterprises (SME) In Indonesia. International Journal of Economic Research. 13(8). 3531-3538.

Muda, I, M.Sihombing, E.Jumilawati and A.Dharsuky. (2017). Factors Affecting The Success of Local Innovation Systems With Government Programs As Moderators. International Journal of Economic Research. 14(16). 272-289.

Muda, I, Rahmanta, Marhayanie and A S Putra. (2018). Institutional Fishermen Economic Development Models and Banking Support in the Development of the Innovation System of Fisheries and Marine Area in North Sumatera. IOP Conference Series: Materials Science and Engineering. 2017.288. doi:10.1088/1757-899X/288/1/012082.

Muda, I, Rahmanta, S. Adi and Marhayanie. (2017). The Role of Working Capital, Productivity, Applied Technology and Selling Market Prices on Fisherman's Revenues. International Journal of Economic Research. 14(16). 291-302.

Muda, I., Erlina, Rina Bukit \& Rahmanta. (2015). The Effect of Fiscal Potential, Fiscal Needs and Internal Control on The Provincial Intergovernmental Transfer Allocation In The Districts/Cities in North Sumatera - Indonesia. International Journal of Management Sciences and Business Research. 3(10). 22-35.

Muda, I., H S Siregar, S A Sembiring, Ramli, H Manurung and Z Zein. (2018). Economic Value of Palm Plantation in North Sumatera and Contribution to Product Domestic Regional Bruto. IOP Conference Series: Materials Science and Engineering 2017. 288. 012080 doi: 10.1088/1757-899X/288/1/012080.

Muda, I. (2014). Analysis on the Timeliness of the Accountability Report by the Treasurer Spending in Task Force Units in Indonesia. International Journal of Academic Research in Accounting, Finance and Management Sciences, 4(4). 176-190.

Muda, I. (2010). Contribution of Teluk Nibung Port Tanjung Balai Asahan to the Local Revenue of Tanjung Balai City. Journal of Economics and Business. 9(1). 17-28.

Muda, I. and A. Rafiki. (2014). Human Resources Development and Performance of Government Provincial Employees: A Study in North Sumatera, Indonesia. Journal of Economics and Behavioral Studies. 6(2).152-162.

Muda, I., \& R.Naibaho (2018). Variables influencing allocation of capital expenditure in Indonesia. IOP Conference Series: Earth and Environmental Science. 2018. 126. doi:10.1088/1755-1315/126/1/012066.

Muda, I., \& A. N. Hasibuan. (2018). Public Discovery of the Concept of Time Value of Money with Economic Value of Time. Emerald Reach Proceedings Series. Vol. 1 pp. 255-261. DOI 10.1108/978-1-78756-793-1-00050.

Muda, I., \& Nurlina. (2018). Influence of Manufacture of Textiles, Clothing and Leather and Manufacture of Paper, Printing and Publishing to the Economic Growth. Emerald Reach Proceedings Series. Vol. 1 pp. 105-111. DOI 10.1108/978-1-78756-793-1-00048.

Muda, I., \& Rasdianto, M. S. L. (2014). Implementation of the Cash Revenue System: A Case Study in the Local Government Task Forces' Units of North Sumatera Province, Indonesia. Information Management \& Business Review, 6(2). 96-108.

Muda, I., (2017). Perception of capital, profit and dividends affect the stock purchase intention in Indonesia public company. Junior Scientific Researcher, 3(1). 9-18.

Muda, I., (2017). The Effect of Allocation of Dividend of the Regional Government-Owned Enterprises and the Empowerment Efforts on the Revenue of Regional Government: The Case of Indonesia. European Research Studies Journal. XX(3A). 223-246.

Muda, I., (2017). The Effect of Supervisory Board Cross-Membership and Supervisory Board Members' Expertise to The Disclosure of Supervisory Board's Report: Empirical Evidence from Indonesia. European Research Studies Journal. XX(3A). 702-716.

Muda, I., and A. H. Harahap, Erlina, S.Ginting, A. Maksum \& E.Abubakar (2018). Factors of quality of financial report of local government in Indonesia. IOP Conference Series: Earth and Environmental Science. 2018. 126 doi:10.1088/1755-1315/126/1/012067. Muda, I., and Nurlina. (2018). Influence of Manufacture of Non-metals, Except Petroleum and Coal, and Manufacture of Basic Metals on Economic Growth. Emerald Reach Proceedings Series. Vol. 1 pp. 185-192. DOI 10.1108/978-1-78756-793-1-00049.

Muda, I., and Windari. (2018) Dimension of an Islamic Model Value on the Existence of Syariah Waltmart. Emerald Reach Proceedings Series. Vol. 1 pp. 321-326. Emerald Publishing Limited. ISSN. 2516-2853. DOI 10.1108/978-1-78756-793-1-00051. 


\section{Academic Journal of Economic Studies}

Vol. 4 (3), pp. 122-132, C 2018 AJES

Muda, I., Panjaitan, S.R, Erlina, S. Ginting, A. Maksum and E. Abubakar. (2018). Model application of Murabahah financing acknowledgement statement of Sharia accounting standard No 59 Year 2002. IOP Conference Series: Earth and Environmental Science. 2018. 126 doi:10.1088/1755-1315/126/1/012071.

Muda, I., Rafiki, A., \& Harahap, M. R. (2014). Factors Influencing Employees' Performance: A Study on the Islamic Banks in Indonesia. International Journal of Business and Social Science, 5(2). 73-80.

Muda, I. (2017). Role of Dividend of Power to Buy Shares in Companies in Indonesia Stock Exchange. Academic Journal of Economic Studies. 3(2), 41-47.

Muda, I. (2017). User Impact of Literacy on Treatment Outcomes Quality Regional Financial Information System. Management Dynamics in the Knowledge Economy. 5(2). 307-326; DOI 10.25019/MDKE/5.2.08.

Muda, I; M. Weldi; Siregar, H.S, \& Indra, N. (2018). The Analysis of Effects of Good Corporate Governance on Earnings Management in Indonesia with Panel Data Approach. Iranian Economic Review. 21(4). 657-669.

Muda, I., R. B., Nasution., Erlina., H. S. Siregar., \& S. Katircioglu (2018). The Effect of the Existence of Large and Medium Industries on the Absorption of Labor in Sumatera Utara. Advances in Economics, Business and Management Research (AEBMR), 1st Economics and Business International Conference 2017 (EBIC 2017). 46, pp. 253-257.

Muda., I., Rahmanta., Marhayanie., \& A.S. Putra., (2018). Institutional Fishermen Economic Development Models and Banking and Financing Institution Support in The Development of The Innovation System. Advances in Economics, Business and Management Research (AEBMR), 46. 263-268.

Muda; I, S. H. Sidauruk, H. S. Siregar, Nurzaimah. (2018). The Effect of Corporate Social Responsibility on Company's Value with Common Effects Model (CEM), Fixed Effects Model (FEM) and Random Effects Model (REM) Approaches (Empirical Evidence in Indonesia Stock Exchange). QualityAccess to Success. 19(165). 94-102.

Nasir, A. Yesi M.Basri, Kamaliah \& Muda, I. (2017). Effectiveness of Potential Tax Region as the Real Local Revenue Sources in Riau Coastal Area. International Journal of Economic Research. 14(12). 313-324.

Nasution, R.B., Muda., I., Erlina., Siregar, H.S. \& Setareh, K. (2018). Variation of Industrial Type Contributions on Working Performance. Advances in Economics, Business and Management Research (AEBMR), 1st Economics and Business International Conference 2017 (EBIC 2017). 46. 258-262.

Nenny (2008). Creative Industry, Economic Journal. 13(3). 17-25.

Nurlina \& Muda, I. (2017). The Analysis of the Effects of Capital Expenditure and Human Development Index on Economic Growth and Poverty in East Aceh Regency. International Journal of Economic Research. 14(16). 395-409.

Nurzaimah, Rasdianto \& Muda, I. (2016). The skills and understanding of rural enterprise management of the preparation of financial statements using Financial Accounting Standards (IFRs) financial statement on the Entities without Public Accountability (ETAP) framework on the implementation of village administration law. International Journal of Applied Business and Economic Research. 14(11). 7417-7429.

Pohan, N., Badaruddin, R.F Dalimunthe, A. Purwoko, \& Muda, I., (2018). The Effects of Human Resource Development and Institutional Arrangements on Performance, Service Quality and Area Development in Indonesia. QualityAccess to Success. 19(163). 94-102.

Rasdianto, Nurzaimah \& Muda, I. (2014). Analysis on the Timeliness of the Accountability Report by the Treasurer Spending in Task Force Units in Indonesia. International Journal of Academic Research in Accounting, Finance and Management Sciences. 4(4). 176190. http://dx.doi.org/10.6007/IJARAFMS/v4-i4/1304.

Sadalia, .Isfenti. Nur Ahmadi Bi Rahamani \& Muda, I. (2017). The Significance of Internet Based Financial Information Disclosure on Corporates' Shares in Indonesia. International Journal of Economic Research. 14(12). 337-346.

Sadalia, Isfenti, M. H. Kautsar, N. Irawati and I, Muda. (2018). Analysis of the efficiency performance of Sharia and conventional banks using stochastic frontier analysis. Banks and Bank Systems, 13(2), 27-38. DOI: 10.21511/bbs.13(2).2018.03

Sari, Maya; A. F. Lubis; A. Maksum; P. Lumbanraja \& I. Muda. (2018). The Influence of Organization's Culture and Internal Control to Corporate Governance and Its Impact on BUMN (State-Owned Enterprises) Corporate Performance In Indonesia, Journal of Applied Economic Sciences, Volume XIII, Issue 4(58). Summer 2018. 562 - 575.

Sihombing, Marlon, Muda, I, Jumilawati, E., Dharsuky, A. (2015). The Implementation of Oil Palm Based Regional Innovation System (SIDA) In Supporting The Masterplan For The Acceleration And Expansion Of Indonesia's Economic Development (MP3EI) of The Economic Corridor Of Sumatera-Indonesia. European Journal of Business and Innovation Research. 3(5), $13-24$.

Sihombing, M., Muda., I., E. Jumilawati \& A. Dharsuky. (2018). Effectiveness of Market Results Diversified Palm Products and Constraints of Capital, Financing and Marketing. Advances in Economics, Business and Management Research (AEBMR). 46. $269-273$. Sirojuzilam, Hakim, S., and Muda, I. (2016). Identification of factors of failure of Barisan Mountains Agropolitan area development in North Sumatera - Indonesia. International Journal of Economic Research. 13(5). 2163-2175.

Sirojuzilam, Hakim, S., and Muda, I. (2017). Effect of Private Collaborative as a Moderation of Success of Agropolitan Program. International Journal of Economic Research. 14(16). 304-315.

Sirojuzilam., S.Hakim., and Muda, I, (2018). Role of Planning and Budget to the Development of Agropolitan Area. Advances in Economics, Business and Management Research (AEBMR), 46. 138-142.

Situmorang, S.H, E.S Rini \& Muda, I. (2017). Customer Experience, Net Emotional Value and Net Promoter Score on Muslim Middle Class Women in Medan. International Journal of Economic Research. 14(20). 269-283.

Sugiyono (2008). Business Research Methods. Sixth Mold. Bandung: Alfabeta Publishers.

Sugiyono (2010). Statistics for Research. Bandung: Alfabeta. 


\section{Academic Journal of Economic Studies}

Suriadi, A., Rudjiman, K. M., Nurman, A. and Muda, I. (2015). The Applicative Model of The Village_Owned Enterprises (BUMDES) Development In North Sumatera. Global Journal of Arts, Humanities and Social Sciences 3(12), 48-62.

Syahyunan, Muda' I, Siregar, H.S, Sadalia, I. \& Chandra. G. (2017). The Effect of Learner Index and Income Diversification on the General Bank Stability in Indonesia. Banks and Bank Systems. 12(4). 171-184.

Tarmizi, H.B.,Daulay, M and Muda, I. (2016). The influence of population growth, economic growth and construction cost index on the local revenue of tax on acquisition of land and building after the implementation of law no. 28 of 2009. International Journal of Economic Research. 13(5). 2285-2295.

Tarmizi, HB, Daulay, M., and Muda, I. (2017). Impact of the Economic Growth and Acquisition of Land to the Construction Cost Index in North Sumatera. IOP Conference Series: Materials Science and Engineering. 180. DOI: 10.1088/1757-899X/180/1/012004.

Tjiptono, F. (2010). Marketing Strategy. Yogyakarta: Andi Publisher.

Tripriyono, A. Purwoko, Erlina and Muda, I, (2018). The Effect of the Political Environment and the Economic Environment on the Welfare of Community. Advances in Economics, Business and Management Research (AEBMR), 1st Economics and Business International Conference 2017 (EBIC 2017). 46. 49-53.

Yahya, I, Torong, ZB, and Muda, I. (2017). Influence Behavior in Legislature Budget Development of Regions in the Province of Aceh and North Sumatra. International Journal of Economic Research. 14(8). 147-159.

Zimmerer, T.W., Scarborough, N.M., Wilson, D. (2008). Entrepreneurship and Small Business Management. Jakarta: Salemba Publishers. 